\title{
Article \\ Theopolitics of the Orthodox World-Autocephaly of the Orthodox Churches as a Political, Not Theological Problem
}

\author{
Vladimír Baar*, Martin Solík*(D), Barbara Baarová and Jan Graf
}

\begin{abstract}
Department of Human Geography and Regional Development, Faculty of Science, University of Ostrava, 71000 Ostrava, Czech Republic; barbara.baarova@osu.cz (B.B.); P21090@student.osu.cz (J.G.)

* Correspondence: vladimir.baar@osu.cz (V.B.); martin.solik@osu.cz (M.S.)
\end{abstract}

\begin{abstract}
The recognition of the autocephaly of the Ukrainian Orthodox Church (UOC) by the Ecumenical Patriarchate in 2019 sparked a debate in the Orthodox world about the legitimacy of such an act. In the present study, we aim to explain, through the concept of theopolitics, this event which has caused a schism in the contemporary Orthodox Church. Following a brief introduction to Buber's concept of theopolitics, we focus on a historical overview, demonstrating that the problems of the Orthodox world do not originate in theological issues, as it might seem at first glance, but primarily in political issues. The case of the autocephaly of the Ukrainian Orthodox Church proves the importance of theopolitics.
\end{abstract}

Keywords: theopolitics; Orthodox churches; Russia; Ukraine; Ecumenical Patriarchate; Kyiv

Citation: Baar, Vladimír, Martin Solík, Barbara Baarová, and Jan Graf. 2022. Theopolitics of the Orthodox World-Autocephaly of the Orthodox Churches as a Political, Not Theological Problem. Religions 13: 116. https://doi.org/10.3390/ rel13020116

Academic Editors: Aje Carlbom and John Jillions

Received: 5 October 2021

Accepted: 14 January 2022

Published: 25 January 2022

Publisher's Note: MDPI stays neutral with regard to jurisdictional claims in published maps and institutional affiliations.

Copyright: (C) 2022 by the authors. Licensee MDPI, Basel, Switzerland. This article is an open access article distributed under the terms and conditions of the Creative Commons Attribution (CC BY) license (https:// creativecommons.org/licenses/by/ $4.0 /)$.

\section{Introduction}

At the collapse of the Soviet Union (USSR), secular political issues had already been reflected in the religious sphere, although Christian churches, in particular, were just gaining ground in an atheised society at that time, and the communist ideology had made space for the return of religion. Religious disputes remained overshadowed by political events, particularly Russia's efforts to reassert its geopolitical influence in the post-Soviet and, subsequently, post-communist regions, such as Russia's early support for Abkhazian, South Ossetian, and Transnistrian separatists; its support for the increasingly autocratic regime in Belarus; its military aggression against Georgia in 2008; and above all, its unprecedented annexation of Ukraine's Crimea and military support for Donbas separatists in eastern Ukraine in 2014. Religious diplomacy has, thus, developed against the backdrop of the highly publicised events mentioned above. It has remained in the shadow of the attention of the conventional state diplomacy; however, it became more visible after the recognition of the autocephaly of the Orthodox Church of Ukraine by the Patriarch of Constantinople in January 2019. This act triggered a wide-ranging debate among Orthodox churches, or rather, their top leaders, exposing significant differences of opinion among them. It should be stated that the differences certainly do not concern theological issues but political ones, although they are often cloaked in theological rhetoric.

Since its inception, Eastern Christianity has been polycentric and heavily subject to political changes, especially the emergence or disappearance of statehood. In the theological sphere, this dependence became apparent as early as the 4th-6th centuries (the schism in the Egyptian Alexandrian, Syrian Antiochian, and Armenian churches, dominated by Miaphysites over Orthodox Christians). The patriarchates of Alexandria and Antiochia endured this period but were considerably weakened, while Miaphysitism completely replaced the Orthodox trend in the Armenian Church. However, this theological split already had a strong geopolitical background-dissatisfaction with Greek domination within the Eastern Roman (Byzantine) Empire. It should be noted that ethnocultural differences also played a role. In this respect, the Bulgarians in the Balkans went even further-after 
establishing independent Bulgaria, they broke ecclesiastical ties with the Patriarchate of Constantinople and constituted their own autocephalous Patriarchate. After losing their statehood in 1018, the Bulgarian Orthodox Church also ceased to exist ${ }^{1}$. However, as soon as the Bulgarians regained their statehood in 1185, the autocephalous Patriarchate was re-established with its seat in Tarnovo. ${ }^{2}$ Three years after they lost their independence and were subjected to the Ottoman Empire (1393), the Patriarchate of Tarnovo was abolished and subordinated to Constantinople. When the Ottoman Sultan restored the Bulgarian Church as an independent exarchate in 1870 against the will of the Ecumenical Patriarch, it took 75 years until the Patriarch recognised Bulgarian autocephaly in 1945. Bulgaria is a prime example of the existence of independent (autocephalous) Eastern Churches-they had existed for some time as de facto states of sorts seeking recognition primarily from the Patriarch of Constantinople to have their autocephaly perceived by others as real-de jure, according to canon law. Nevertheless, theologians disagree on interpreting canon law, just like lawyers disagree on the interpretation of international law.

With the emergence of nation-states in the second half of the 19th century, the topic concerning the relationship between nationalism and religion arose in Orthodoxy. The Patriarch of Constantinople, for example, encountered calls for autonomy or autocephaly from the ecclesiastical and political leaders of the newly formed Romania, Bulgaria, and Serbia. While the Patriarchate gradually recognised the autocephaly of the churches in the new Balkan countries, as early as 1872, it also denounced ethnophyletism, referring to a situation when a local church's identity solely relied on nationality (Werth 2006). This relationship between church and nation emerged after World War I, when the Russian, Ottoman, and Austro-Hungarian empires collapsed, and again after the USSR's collapse in 1991.

The present study aims to map the theopolitics of Orthodox churches, starting from the founding of the earliest Orthodox Church in Kievan Rus in the 9th century until 2019, when the Patriarchate of Constantinople recognised the autocephaly of the Ukrainian Orthodox Church. This decision caused a schism in the Orthodox world, as not all Orthodox churches have concurred with it, most noticeably the Russian Orthodox Church. After introducing the theoretical background and the theopolitics, a short historical excursus follows, charting the rivalry between the Russian Orthodox Church and other Orthodox churches. We consider the disputes within the Orthodox world to have a distinctly political, not theological, dimension. Furthermore, as we emphasise, this phenomenon has persisted since the founding of the earliest Orthodox Church.

\section{Theoretical Background, Theopolitics}

The current crisis of Orthodox Christianity is not the first and certainly not the last. Disputes over canonical boundaries and the independence of some Orthodox churches form part of a specific category of geopolitics that can be called theopolitics. This term was coined by the Jewish philosopher and professor of Judaism, Martin Buber (1878-1975), in his work Kingship of God (Buber 1932). Although his publication focused on the political aspects of the Bible-or more specifically, the Old Testament-the increase in religious conflicts in modern times has revived interest in his work. In particular, Brody (2015) and Schaefer (2017) analyse Buber's debates on biblical meanings and assess their specific political implications for anarchists, socialists, Zionists, Nazis, Britons, and Palestinians. Brody (2018) further reveals how Buber's passionate commitment to the rule of God without a mediator brought him face-to-face with the Zionist movement in danger of repeating ancient mistakes. Brody argues that Buber's support for Israel stemmed from a radically rich and complex understanding of the nature of the Jewish mission on Earth, borne out of an anarchist reading of the Bible.

The Catholic theopolitics of the German lawyer and geopolitician Carl Schmitt (18881985) was assessed by Moore (2020). His article explores the theological dimensions of sovereignty and prompts a more detailed examination of the theopolitical discourses of legality and legitimacy conducted within the predominantly secular discipline of inter- 
national relations. By tracing the pluralistic dimensions of sovereignty-legal, popular, and theopolitical—we can discern how sovereignty is operationalised through several different political registers. If the study of sovereignty is conflated with issues concerning the preferred forms of government (whether secular, religious, democratic, and/or legal), one may overlook the comprehensive historical sociology of sovereignty. Anderson's (2010) dissertation focused on biblical theopolitics and its influence on growing American evangelical Christian nationalism. Another Ph.D. thesis examined the theopolitical influence of Eastern Christianity on democratic consolidation (Slavov 2016). An interesting paper on the spiritual geopolitics of Constantinople in the geo-religious space was published by Bogdanović (2016).

Kormina and Naumescu (2020) discuss the recent theopolitical crisis in Ukraine. Their article examines the recent "schism" in Eastern Orthodoxy to demonstrate how closely intertwined religion and politics are in disputes over territory and sovereignty. They argue that two logics come into play in this conflict: one grounded in the theological-political concept of "canonical territory", the other in the notion of "communion" underlying the Christian communion. The former is invoked in claims for national sovereignty and imperial supremacy, while the latter can make or break communities of faith. Drawing parallels between the post-socialist revival of religion in Ukraine and the current domestic mobilisation, it is possible to demonstrate how such contradictory logics shape the fate of people, churches, and states. Furthermore, one must not forget Islamic theopolitics, about which dozens of articles (e.g., Sayyid 2009; March 2015, etc.) and scholarly monographs (e.g., Scott 2010 or Karagiannis 2018) have been written in the past two decades.

Christianity has experienced many schisms that have rendered it the most theologically diverse religion in the world. Even the earliest heresies of the Arians, Nestorians, and especially the Miaphysites in the first millennium after Christ were motivated theologically and politically. The fundamental schism between Western and Eastern Christianity in 1054 was primarily politically motivated; the theological dispute over the so-called filioque played only a secondary role. The Western Catholic Church managed to maintain a unified structure for almost five centuries before the arrival of another schism represented by various Protestant movements. Since its beginning, Eastern Christianity was divided into separate churches, recognising each other and having no theological differences. Nevertheless, they branded as heretics those who deviated from their dogmas. It should be added that all Orthodox churches became politically subordinated to (or at least dependent on) Islamic powers. Only the Russian Orthodox Church (partly also the Georgian Church, which the Russian one later absorbed) managed to break free. The Orthodox Churches split for political reasons (e.g., under pressure from secular institutions) or because of the conclusion of the union of a part of the Orthodox Church with the Roman Catholic Church, due to disagreement with the reforms (the emergence of Old Rite and Old Calendarist Churches) or deviation from the fundamental dogmas of Orthodoxy (Spiritual Christians).

However, the highest number of splits resulted from the old tradition, according to which the newly emerging states established their own churches (even states with Orthodox Christians as a minority, such as Albania or Poland). Thus, the liberation of the Balkan nations from Ottoman rule during the nineteenth century gave rise to new churches that had to wait for some time for their recognition by elders. Some have not been recognised to this day (in Montenegro and Northern Macedonia). This also applies to countries that could not maintain statehood, and their newly established de facto autocephalous churches could only continue their activities in exile (the Belarusian Autocephalous Orthodox Church still functions this way). The Ukrainian Autocephalous Orthodox Church existed until the collapse of the USSR, and Ukraine has succeeded, through long-term political and theological diplomacy, in achieving recognition of its autocephaly by several other autocephalous churches, thus initiating a theopolitical debate (Ponomariov 2019; Kormina and Naumescu 2020).

The position of the Orthodox churches largely resembles the situation of states in the world system. The de jure mutually recognised states correspond to the mutually 
recognised autocephalous churches. Contrarily, some states are not recognised by others (e.g., Israel or The People's Republic of China), which is the case of the new church in Ukraine and the Orthodox Church in America.

Finally, some states exist de facto but are not recognised by the countries that exist de jure (e.g., Transnistria) or only by some of them (e.g., Abkhazia). Accordingly, there are Orthodox churches that de facto exercise canon law in "their" states but are not recognised de jure by others (the Orthodox churches in Northern Macedonia and Montenegro). Moreover, governments of some states cannot exercise jurisdiction in their own countries (e.g., Tibetan or Saharan); there is also the Belarusian Church in exile mentioned above.

\section{The Role of the Patriarchate of Constantinople}

The influence of the Ecumenical Patriarchate relies primarily on the historical tradition of putting Constantinople as the first among equals within the hierarchy of the Orthodox world. In the first centuries of Christianised Rome, five patriarchates (pentarchate) were created, with Rome in the first place and Constantinople in second place. Following the disagreements at the 8th Ecumenical Council between Rome and the Eastern Patriarchates, the Roman Patriarchate pursued its own path, and Constantinople became "first among equals" within the hierarchy of the Eastern Churches. Even though there is canonical theological unity between them, political disputes have and continue to exist to this day. The term theopolitics is used for these disputes set in a political-geographical context. The position described above gives the Ecumenical Patriarchate the right to convene and preside over pan-Orthodox councils with the consent of other churches. The Ecumenical Patriarchate has a vast network of international contacts with many Christian churches, not only Orthodox. The relationship between Constantinople and Rome, established after centuries of disputes in the 1960s, has become the most important of these contacts.

Elected in 1991, Patriarch Bartholomew is seen as an ambitious leader seeking to protect and enhance the status of the Ecumenical See. Building on the legacy of Athenagoras (Patriarch from 1948 to 1972), he promotes reconciliation and dialogue between Christian denominations. The Ecumenical Patriarchate's weakness is that it is neither supported nor defended by a strong state due to its seat in Istanbul. On the other hand, this fact also gives it a particular advantage because none of the other Orthodox churches and countries can suspect the Ecumenical Patriarchate of being influenced by the mother state. Thus, the Patriarchate is a recognised arbiter in disputes between Orthodox churches. The Ecumenical Patriarchate's significant symbolic power also stems from its control of the spiritual centre of Orthodoxy, Mount Athos in Greece. Although some of the monasteries in this autonomous monastic republic ${ }^{3}$ are traditionally affiliated with other countries (Serbia, Bulgaria, and Russia), they all are subject to the jurisdiction of the Ecumenical Patriarch. Logically, the Patriarch of Moscow is interested in assuming the role of Ecumenical Patriarch, given the support of the state, which is still a significant geopolitical power. Thanks to the support of the state, the Russian Orthodox Church had behaved that way since the 17th century, when it occupied the canonical territories of Constantinople shortly after its political control by the state. Under Soviet rule, it continued to do so and even granted autocephaly to other churches without the consent of Constantinople and the traditional patriarchates.

\section{The Historical Context of the Constantinople-Russian Rivalry}

The Russian Orthodox Church is de facto the longest-existing autocephalous churchfrom 1448, when it declared its independence, until its recognition by Constantinople in 1589. This act had a strong geopolitical significance. By that year, Constantinople had been Ottoman Istanbul for more than a century, while Moscow had already experienced a rise in power and territory. During the reign of the last Rurik Theodore, the real power belonged to Boris Godunov, who managed to arrange a visit of the Ecumenical Patriarch Jeremiah II to obtain autocephaly for the Russian Church. The Patriarch arrived in Moscow on 13 July 1588; however, negotiations dragged on for many months, and even Russian sources admitted that Jeremiah was effectively kept under house arrest. He did not personally 
confer autocephaly and patriarchal dignity until May 1589 (thus, no official tomos was issued). The Patriarch of Alexandria, Meletius Pigas, vigorously challenged his decision and questioned the canonical legality of the act. He was convinced that Jeremiah had been forced to grant autocephaly by force and trickery of the Russians (Gramota ... ).

Despite this success, Moscow was not entirely satisfied. It wanted the Moscow Patriarchal See to occupy the third place in the Orthodox diptych ${ }^{4}$ after the Ecumenical and Alexandrian patriarchates. However, this demand was not accepted. Nevertheless, the decision of the Ecumenical Patriarch was approved by the convened council in 1590. A letter confirming autocephaly and the Patriarchate was delivered to Moscow by the Metropolitan of Tarnovo. As Moscow was only awarded fifth place in the diptych, the Moscow government rejected the letter ${ }^{5}$ (Грамота undated). Nevertheless, the intransigent attitude did not change anything. In February 1593, a new council of the Eastern hierarchs was held in Constantinople, attended by the Russian envoy Afanasyev, confirming the earlier decision. The Patriarch of Alexandria also signed it, and this time, Moscow accepted the decision.

The newly established states wanted to have their own autocephalous ecclesiastical boundaries; this represented a distinctive aspect of Eastern Christianity. However, by changing the state borders, the canonical borders were also forcibly altered-a practice used by Constantinople ${ }^{6}$ in the single case of Bulgaria and later applied by Russia on several occasions. When the Russian Orthodox Church occupied Polish, Ukrainian, or Moldavian territories, it transferred the believers from the jurisdiction of Constantinople without its consent and subjected them to the jurisdiction of the Russian Orthodox Church. Russia even went so far as to abolish the autocephaly of the Georgian Orthodox Church a few years (1810) after the annexation of Georgia (1801). ${ }^{7}$ Thus, it uncompromisingly enforced the model of "one state, one church". It could afford such a course of action because, at that time, it was the only Orthodox Church operating in an independent state with a majority of Orthodox believers. With the exception of the autonomous Orthodox Serbian Metropolitanate in the Habsburg Monarchy, ${ }^{9}$ most of the autocephalous churches (except for the Georgian Orthodox Church) were subjected to the Ottoman Empire. It is important to note that the Russian Orthodox Church was entirely subordinated to the state in 1721. After the death of Patriarch Adrian in 1700, the Tsar denied the election of a new patriarch and instead appointed a guardian of the Patriarchal See (patriarch locum tenens), who was entirely under his control. As part of reforms to prevent the Church from becoming a state within a state, he established the Most Holy Synod on 25 January 1721. He did not, in fact, abolish the Patriarchate by law, which suggests, in agreement with Destivelle, that he only suspended its activities. However, it is possible to provide an alternative interpretation since the restoration of the Patriarchate's activities was approved by the Local Governing Council of the Russian Orthodox Church on 28 October 2017. The Russian Orthodox Church became a state authority. It should be mentioned that during this synodal period, it was called Rossiyskaya Pravoslavnaya Tserkov (Российская Православная Церковь), and its seat was transferred to St. Petersburg (it returned to Moscow with the restoration of the Patriarchate in 1917). The name was used until the new restoration of the Patriarchate in 1943 (the office was abolished in 1925) when it was changed to its present name: Russkaya pravoslavnaya Tserkov (Русская православная церковь).

Everything changed fundamentally when the Romanovs were overthrown, and the Russian Empire collapsed. As a result, the Georgian Orthodox Church declared the restoration of its autocephaly and established its churches in Ukraine and Belarus based on the national principle. The situation became complicated with the rise of atheist communists, who played their own theopolitics with autocephaly. They temporarily separated the Belarusian and Ukrainian churches from the Russian churches, as their primary goal was to weaken the Russian Orthodox Church (Воронин 1992). ${ }^{10}$ However, after the accession of Stalin, they were dissolved by 1937. The few bishops who emigrated managed to maintain formally independent churches in American and Canadian exile. ${ }^{11}$ The Belarusian Church is still active there as a result of the repressive rule of President Lukashenko. After 
establishing the USSR, Orthodox believers in Poland, Finland, and Estonia appealed to the Ecumenical Patriarch, who granted autocephaly ${ }^{12}$ to the Polish Church in 1924 and autonomy to the Finnish and Estonian Churches, which continue to exist to this day. Latvia took a similar step only in 1935. Soviet aggression in 1939-1940 led to the subordination of the Estonian, Latvian, and Polish Churches to Moscow; as Poland was not annexed to the USSR, Moscow subsequently transferred the Polish Orthodox Church without the consent of Constantinople and granted it autocephaly in $1948 .{ }^{13}$

The Russian Orthodox Church was already completely controlled by the Bolsheviks by the mid-1920s, and they prevented the election of a new Patriarch after the death of Patriarch Tikhon in 1925. Metropolitan Sergei, whose collaboration with the regime was called "sergeism" (Одинцов 1994), became the de facto head of the Church. Stalin rewarded him in the autumn of 1943 when he was appointed Patriarch. ${ }^{14}$ He died the following year, and Alexy I became Patriarch and continued his policy. Stalin wanted to capitalise on the victory over Hitler's Germany, and as early as late May 1945, he sent him on a month-long trip to the three old patriarchates of Alexandria, Antioch, and Jerusalem with an important assignment. He was to persuade them to move the centre of Orthodoxy from the Patriarchate of Constantinople to Moscow. Stalin was well aware of the longstanding weakening of Orthodoxy in the Middle East and Turkey, and Moscow, as the newly recognised power, was to remedy this - to become the Vatican of Orthodoxy and, of course, to strengthen the USSR's influence in this strategic region. The plan ultimately failed, ${ }^{15}$ but Stalin did not give up. Aware of the conservatism of Orthodox Christianity and dissatisfied with the Uniate "apostates" who recognised the Catholic Pope as the supreme head of Christianity, he tried to invite the hierarchs of all Orthodox churches to Moscow. However, he scheduled the meeting for July 1948, when the Russian Orthodox Church celebrated the 500th anniversary of the unilateral proclamation of autocephaly under the supervision of the authorities and the police. The meeting was conceived as a pan-Orthodox council "to settle the question of granting the title of ecumenical to the Moscow Patriarchate" (Каиль 2017).

Nevertheless, the patriarchs of the ancient patriarchates did not accept the invitation, and the plan failed utterly. Moscow finally enforced its ecclesiastical policy in the Central European vassal states by granting the aforementioned autocephaly to the Church in Poland and Czechoslovakia (1951). ${ }^{16}$ Similarly, Moscow granted autocephaly to the Orthodox Church in America in 1970 (Tomos of Autocephaly 1970). ${ }^{17}$ The bipolarity of geopolitics manifested in the theopolitics due to the political domination of the churches in the communist countries. Nevertheless, Constantinople succumbed to pressure from Moscow and in 1978 declared the tomoses previously granted to churches in Estonia and Latvia to be non-functional (Leonidov and Prekop 2019), but not null and void, as developments after the collapse of the USSR have shown.

\section{Competition for the Kyiv Metropolitanate}

The fact that Tsar Peter the Great had already managed to bring the Russian Orthodox Church under the control of the state, which became even stronger after the rise of the Communists, was specific to Russia. In the brief interim (1917-1921) between the collapse of Russian statehood and the declaration of an independent Ukraine, its political and ecclesiastical leaders attempted to create an independent Ukrainian Church. Nevertheless, the time was not ripe for negotiation-and as the subsequent collapse of Russian or Soviet statehood proved, it took almost 30 years before the independence of the Ukrainian Church could be asserted. The independence was enforced against the will of Russia and the Russian Orthodox Church. The point is that just as there have been diverse historical opinions about the origins of statehood in Russia and Ukraine, the disputes over the Orthodox Church, dating back to 988, have also stretched through history. In that year, the Patriarch of Constantinople established the Metropolitanate of Kievan Rus under his jurisdiction. Its representatives carried the title of Metropolitan of Kyiv and all Russia. 
The 13th-century Mongol invasion weakened Kyiv, and in 1299, the Metropolitan moved to Vladimir.

However, a considerable part of Kievan Rus was occupied by Lithuania, and its leaders refused to subject Orthodox believers to Metropolitans residing in another state. Constantinople reacted quickly, establishing another Metropolitanate of Halych in 1302 and Metropolitanate of Lithuania in 1317. The Metropolitanate of Kyiv was transferred from Vladimir to Moscow, the new capital of Russia, in 1325. Nevertheless, Kyiv continued to be included in the titulature of the Metropolitans. Although Moscovite Rus was a vassal of the Mongol-Tatar Golden Horde at that time, it remained autonomous in ecclesiastical matters and, by pressuring the Patriarch of Constantinople, achieved the abolition of the Lithuanian Metropolitanate in 1330 and, two years later, of the Halych Metropolitanate (which, however, was restored in 1337, abolished again in 1347, and restored in 1371. Additionally, Constantinople, under pressure from Lithuania, restored the Lithuanian Metropolitanate in 1354). It follows from the foregoing that the situation in the 14th century was fluid, despite the fact that the area of Lithuania and Muscovite Rus remained under the jurisdiction of the Patriarchate of Constantinople. Patriarch Philotheos Kokkinos decided to counteract the constant changes and decreed in 1375 that after the death of the Metropolitans of Moscow and Halych, both would be subordinated to the Metropolitan of Lithuania.

This soon happened; in 1389, Moscovite Rus was subordinated to the Lithuanian Metropolitan and Halych in 1401. Thus, Eastern Europe had a single Metropolitan for the first time in history. However, the Lithuanian Metropolitan Cyprian died in 1406, and the first Moscow ruler with the title of Grand Duke, Vasily I Dmitrievich (1389-1425), achieved the restoration of the Metropolitanate of Kyiv in 1408, albeit with the seat in Moscow. The situation became increasingly complicated because no Metropolitan had been elected in Lithuania for a long time. In 1414, Lithuanian Grand Duke Vytautas asked the Patriarch to appoint his candidate; however, the Patriarch refused due to the time delay. Therefore, Vytautas appointed Metropolitan Gregory himself and proclaimed the establishment of an autocephalous Lithuanian Orthodox Church. He expected the new Metropolitan to sign a union with the Catholic Church-but this did not happen. When the Metropolitan died in 1420, Vytautas decided to settle relations with Moscow and recognised the subordination of the Lithuanian Orthodox to the Metropolitanate of Kyiv in Moscow (Boronas 2013). These approximately five decades were marked by geopolitical rivalry over the still pagan Lithuania, or rather the Christianisation of the Lithuanian Gediminas dynasty, as the ruling dynasty and some nobility still maintained the traditional Lithuanian faith. However, the majority of the Slavic population was Orthodox, and a minority were Catholics. The declared preferences of Lithuania by Constantinople were motivated by the desire to win Gediminas to the Orthodox faith. In 1384, a Lithuanian delegation even negotiated in Moscow the marriage of the heir to the Lithuanian throne, Jogaila, to the daughter of Vasiliy of Don and the establishment of Orthodoxy as the state religion. Eventually, however, Jogaila accepted the offer of Catholic Poland and married Hedwig, heiress to the Polish throne, in 1386 and embraced the Catholic faith. Nevertheless, his relatives retained their ties to Orthodoxy. For example, his cousin Vytautas received Catholic baptism as early as 1384, but seven years later, he married his daughter Sophia to the Grand Duke of Moscow, Vasiliy I. This connection was one of the reasons why Vytautas retreated from the project of his own autocephalous church.

Further development was influenced by the weakening of Byzantium by the Ottoman Turks and, simultaneously, the diminishing hold of the Golden Horde on Moscow. The Patriarch of Constantinople, together with the Metropolitan of Kyiv, Isidore (originally an educated Greek), attempted to negotiate with the Pope for the help of Western Christians, and in 1439, signed the so-called Union of Florence, recognising the Pope as the supreme ecclesiastical authority. However, the believers in Constantinople or Moscow did not accept their activity-Isidore was even arrested (but managed to escape). As Constantinople was besieged on all sides by the Turks, Moscow decided to elect its own Russian Metropolitan 
Ivan (Ion) in 1448 and declare autocephaly. Five years later, Constantinople was conquered and became Istanbul, but the Patriarchate was preserved. He took his time recognising the Russian autocephaly. It happened only in 1589 when Patriarch Jeremiah II also awarded the Russian Metropolitan with the title of Patriarch.

After the secession from Constantinople in 1458, the Metropolitanate of Kyiv was renamed the Metropolitanate of Moscow to reflect the reality and relinquished jurisdiction over the Orthodoxy beyond the borders of the Moscow Tsardom for the sake of settling relations. Constantinople responded in the same year by restoring the Metropolitanate of Kyiv in Kyiv, which belonged to Lithuania at that time. Its head received the title of Metropolitan of Kyiv, Halych, and all Russia. The titular status did not change even the Ukrainian ethnic territories, including Kyiv, which were handed over to the Polish Crown at the conclusion of the Polish-Lithuanian Union of Lublin (1569). The Catholic bistate pushed hard for the Catholicisation of all Orthodoxy in its territory and achieved it in 1596 with the conclusion of the so-called Union of Brest. The entire Metropolitanate of Kyiv was subordinated to the Pope as the Ruthenian Uniate Church. ${ }^{18}$

The dissolution of the Kyiv Metropolitanate did not mean that Orthodoxy ceased to exist in Poland. It was an opportunity for Moscow, which, however, did not want to clash with Poland and react to the new situation. On the other hand, Kyiv lacked a canonically consecrated bishop, a situation that was remedied in 1620 by the Patriarch Theophanes III of Jerusalem. Paradoxically, Constantinople recognised the restoration of the Metropolitanate of Kyiv only after eleven years and accepted it back under its jurisdiction. By mid-century, the Ukrainian created a de facto independent state in central Ukraine under Hetman Khmelnytsky, ushering in a period of ecclesiastical flourishing and spreading the Ukrainian language. Nevertheless, by 1654, Russia had already seized left-bank Ukraine and began to assert its submission to Moscow in the ecclesiastical sphere. The second period of conflict between Moscow and Constantinople followed. In 1686, Moscow took the Metropolitanate under its jurisdiction and reduced it to a mere bishopric. The bishop was entitled to the honorary title "Metropolitan of Kyiv, Halych, and all Little Russia". The title then further changed $^{19}$, but the diocese of Kyiv was only one of many-the fact that the Christianisation of the Eastern Slavs began there was nowhere mentioned. Little Russia disappeared from the ecclesiastical and geographical nomenclature, and the toponyms Ukraine and Ukrainian were not allowed to be used.

In 1686, Constantinople granted Moscow permission to ordain the Metropolitanate of Kyiv because the conflicts between the Russian and Ottoman empires made travel to Kyiv difficult. Moscow interpreted the Patriarchal Act of 1686 as Constantinople's transfer of the Kyiv Metropolis to Moscow. In 1924, in his Tomos on granting autocephaly to the Polish Orthodox Church, Patriarch Gregory VII of Constantinople mentioned the noncanonical nature of the transfer of the Metropolitanate of Kyiv in 1686. However, it was only in 2018 that Patriarch Bartholomew decided to reassume the old canonical territory under Constantinople's jurisdiction. By doing so, he reversed Dionysius' decision, which infuriated the Russian Patriarch Kirill. Although Bartholomew essentially carried out the equivalent of the act of the Russian Orthodox Church regarding the Polish Orthodox Church, revoking the Constantinople Tomos in 1924 (requested freely by the Polish Church and state), it took the Polish canonical territory under its wing, created a new Polish Church under its jurisdiction, and granted it autocephaly (Bystrytska and Volik 2021). It then took advantage of the fact that the Communists had taken over Poland and the Church. The difference of the 2018 act is that Constantinople revoked the forced act of consent (the Russian Orthodox Church did not ask whether it agreed to the seizure in 1686). Instead, Constantinople responded to the request of the independent state of Ukraine to take its canonical territory back under its jurisdiction, create a new Ukrainian Church in it, and grant it autocephaly. 


\section{Continuation of Theopolitics}

The historical overview has shown that theopolitics have been an integral part of political development in the Orthodox world. The competition for the Kyiv Metropolitanate between Moscow, Lithuania, and later Poland constituted the first phase of the competition for Ukrainian territory. It still took place within the framework of the Church of Constantinople; however, the second phase started in 1448, when Moscow began to conduct its ecclesiastical affairs entirely independently. The Polish Catholic side lost the contest for the Metropolitanate of Kyiv between Poland and Moscow due to its uncompromising attitude towards the Orthodox believers. Besides the serfs, they comprised, above all, the free Ukrainian Cossacks, who were literally driven into the arms of Moscow by Polish policy. Moscow consecutively banned the activities of the Greek Catholic Church in Russia. The activities of the Catholic Church were tolerated. Since the declaration of ecclesiastical autocephaly, Russia has promoted the motto "one state-one church". Therefore, in all the annexed territories (e.g., Bessarabia), it subordinated the Orthodox believers to its jurisdiction, although the Church of Constantinople, to whom they had been still subordinated, disagreed. The Russian Orthodox Church went even further in Georgia in coordination with the state and abolished the autocephalous Georgian Church.

With the collapse of the Russian Empire, attempts to create state entities emerged. They were ultimately unsuccessful in the case of Ukraine, Belarus, and Georgia; however, in countries with strong Orthodox minorities (Finland, Estonia, Latvia, Poland), statehood was indeed established. The historical part of eastern Moldova (Bessarabia) joined the predominantly Orthodox Romania. Theopolitics went hand in hand with geopolitics and resulted in a new division of ecclesiastical structures in the post-Imperial Russian region. The victory of the Bolsheviks, whose communist ideology targeted all religions, meant the re-subordination of church structures to the state. Logically, the newly created or reconstituted states opposed such developments, and Poland, Finland, and Estonia turned to Constantinople to take the believers under the Patriarch's jurisdiction. The Moldovans in Bessarabia, for example, transferred to the canonical jurisdiction of the Romanian Orthodox Church with the consent of Constantinople (Biserica Adevarat Ortodoxă din Moldova și Altii 2007).

\section{The First Post-Soviet Conflict between Moscow and Constantinople}

The breakdown of relations between Moscow and Constantinople over Ukraine in 2018 was not the first occurrence of such problems. The same happened in Estonia in 1996 when a ten-year stalemate (1993-2002) culminated, having its roots in post-World War I. The Orthodox Church in then-independent Estonia had been removed from Moscow's jurisdiction at its request since 1923 and subordinated as autonomous to Constantinople. After the annexation of Estonia, the Moscow Patriarchate took the Estonian Church under its jurisdiction. When Estonia regained its independence in the early 1990s, there were two contenders for the succession of the Orthodox Church: the Church subject to the Moscow Patriarchate and the Church that had survived the Soviet period in exile. However, the position of the returnees was difficult because in 1978, the Patriarch of Constantinople, at the insistence of the Russian Patriarch, declared the Tomos of 1923 null and void. ${ }^{20}$ It was significant to the Church that Estonia legally restored its statehood, granted citizenship to the descendants of its pre-War citizens, and returned all nationalised property to its pre-War owners. The government was also open to the demands of the exiled Church and its supporters in Estonia. Attempts of the Moscow Patriarchate to declare itself the descendant of the pre-War Church were rejected, as were Patriarch Alexei's proposals to establish an autocephalous Church in Estonia that would be subordinate to neither Moscow nor Constantinople. Although the reprivatisation of property played an essential role in this process, it is clear that Estonian politicians rightly feared that an autocephalous church could serve as an instrument of Russian foreign policy since the vast majority of Orthodox believers were ethnic Russians who settled in Estonia during the Soviet era. 
After intense negotiations, in February 1996, the Patriarch of Constantinople announced the renewal of the 1923 Tomos, establishing the autonomy of the Estonian Orthodox Church. Moscow reacted by worsening relations with the Estonian Church. Nevertheless, this did not last long-in April of that year, representatives of the two patriarchates agreed at a meeting in Zurich that Estonia could have two Orthodox churches: one for Estonians ${ }^{21}$ and one for Russians. Negotiations continued, and political, administrative, and legal issues were settled over several years. In 2002, Estonia officially recognised two Orthodox churches: the Estonian Apostolic Orthodox Church under Constantinople and the Estonian Orthodox Church of the Moscow Patriarchate. The congregations were free to choose which church they wanted to belong to; those who did not explicitly choose remained open to both groups of believers. The question arises whether the current split between Moscow and Constantinople, as Moscow Patriarchate forbids its believers to visit churches under Constantinople's jurisdiction, will also lead to tensions in Estonia.

The Latvian Orthodox Church suffered a similar fate. However, as its believers were predominantly ethnically Russian, it was only in 1935 that Latvia asked to be transferred to Constantinople's jurisdiction. This occurred in the following year, but Soviet annexation in 1940 ended such activities. The church did not remain in exile as the vast majority of Orthodox believers were Russians. After the restoration of independence, several Russian bishops decided to withdraw from the Latvian Church under the Russian Orthodox Church and, in 1994, applied for registration as an Orthodox religious association. It was the only option, as the Latvian constitution allowed only one church of this orientation to be registered. Court cases followed, which the newly established church lost. In 2011, the Latvian Autonomous Orthodox Church asked Constantinople to take over its jurisdiction. At the same time, it appointed itself the legal successor of the pre-War autonomous church. After the problems with Estonia, Constantinople did not want to become involved in another dispute with Moscow and made a Solomonic decision: it agreed that the name of the Patriarch of Constantinople should be mentioned during the liturgy but has not yet officially incorporated the Church under its jurisdiction. However, the Latvian Autonomous Orthodox Church brought its request to the Constitutional Court, which ruled on 27 April 2018 that it was entitled to state registration. The registration was supposed to occur on 18 November 2019, the anniversary of Latvia's independence. However, it took place on 24 October 2019. On this day in 1936, the jurisdiction of the Latvian Orthodox Autonomous Church was passed to the Patriarchate of Constantinople (Приймак 2019). Although the Patriarchate has not yet decided on restoring the Tomos as of August 2021, it is reasonable to assume that it will happen (Фаустова 2021). Nevertheless, Latvia has still decided to weaken the influence of the Russian Orthodox Church; the Latvian MPs approved amendments to the Orthodox Church Law, requiring the Metropolitan, all archbishops, bishops, and candidates for these positions to be Latvian citizens (Кишиневский 2019). Although Russian sources report that the law applies specifically to the Orthodox Church, its validity is universal and applies to all churches (the Pope has already agreed).

The situation in Lithuania was utterly different. Most Orthodox Christians were Russians, even though they lived mainly in Vilnius, which was annexed to Poland after World War I. In Lithuania, they were scattered and made up only a little over $1 \%$ of the population, about 22,000 people (Rimestad 2012). After the Second World War outbreak, Vilnius was occupied by the Red Army on 19 September 1939, based on the RibbentropMolotov Pact. According to Russian plans, Vilnius was to become the capital of Belarus. However, during the Lithuanian-Russian talks in Moscow on 10 October 1939, it was agreed that the city and its surroundings would be handed over to Lithuania in exchange for agreeing to the establishment of Russian military bases on Lithuanian territory. However, everything ended with Soviet annexation in June 1940. During this short period, attempts were made to establish a Lithuanian-Belarusian autocephalous church (Петров 2013). At that time, Belarusians constituted the majority of Orthodox believers; Lithuanians were very few. Nevertheless, it was not the only proposal. Some Lithuanian bishops negotiated with Constantinople for autonomy along with Estonia and Latvia. It should be noted that most 
of them wanted to remain under the Russian Orthodox Church, even though the members of this Church at the time faced the harshest repression from the Soviet Communists.

The small number of Orthodox believers and the loyalty and support of Lithuanian Metropolitan Chrysostomos in the restoration of Lithuanian independence (he was a member of the Sajūds movement and strongly condemned the use of force by the Soviet government during the riots in 1991 in Vilnius) resulted in Lithuania leaving the local Orthodox believers under the jurisdiction of the Russian Orthodox Church, posing many problems. However, after the Ukrainian autocephaly, experts and conservative politicians in Lithuania have concluded that if all the parishes that had belonged to the Metropolitanate of Kyiv in 1686 were transferred to Constantinople in October 2018, the same principle should be applied on Lithuanian territory (Bogdanas 2019). Although official authorities have not yet entered the discussion, proponents of the separation of the Lithuanian Church from Moscow justify the need for such a separation by saying that Ukrainians form a significant minority in the country and that the agreement to grant autocephaly includes the stipulation that Ukrainians living outside Ukrainian territory will be directly subject to Constantinople. According to official data, about 20,000 ethnic Ukrainians live permanently in the country, and more than 18,000 stay temporarily on Lithuanian territory as labour migrants and students. It should be noted that the authorities continue to encourage the influx of people from Ukraine. Therefore, an ecclesiastical structure under the Ecumenical Patriarchate should also be established in Lithuania (Liekis 2019). The Orthodox community in Lithuania is currently more prominent (about 125,000), including more than 100,000 Russians and Russified Belarusians.

\section{Developments in the Ukrainian Crisis}

Although the movement for the recognition of autocephaly in Ukraine has been strong since the country declared its independence (church leaders have sent seven requests to Constantinople), they have remained unanswered. Against the backdrop of the war in the Donbas, the previous Ukrainian President Petro Poroshenko set out to resolve the issue, no doubt expecting to gain political advantage in the upcoming presidential elections. In April 2018, he sent a letter to the Ecumenical Patriarch in Constantinople asking for autocephaly for Ukraine. Two of the existing ecclesiastical structures in Ukraine, the Kyiv Patriarchate and the Ukraine Autonomous Orthodox Church, supported his request. This affirmation of the joint efforts of secular and ecclesiastical institutions made the decision. The fact that several bishops of the Ukrainian Church under the Moscow Patriarchate also expressed their support for autocephaly certainly helped (Вагнер 2018). The Patriarch also stated that "he considers it unfair that 500,000 believers of the Polish Orthodox Church and 100,000 Orthodox believers in Czechia and Slovakia have independent churches, while 40 million Ukrainians do not" (Liik et al. 2019).

Prior to the Holy Synod of the Patriarchate of Constantinople at the end of November 2018, the head of the Department of External Church Relations of the Russian Orthodox Church, Hilarion, initiated visits to other Orthodox churches to gain support for the position of the Russian Church and to prevent the granting of autocephaly. In addition to threats against Ukraine and Constantinople, Moscow has used more subtle methods to oppose the Ecumenical Patriarchate. After Bartholomew's initial steps in the spring of 2018, it became apparent that some churches supported Moscow while others called for internal dialogue. Nevertheless, the Patriarchate of Constantinople continued its actions and reversed the Patriarch's decision of 1686. Moscow immediately hardened its stance and broke off contact with Constantinople in October 2018. The Ecumenical Patriarchate subsequently granted autocephaly to the Ukrainian Church in January 2019.

The Patriarchate of Constantinople, which usually does not comment on the political aspects and only speaks about the religious rights of the Orthodox Church, responded at the end of 2018, accusing the Russian Orthodox Church of politicising autocephaly and pursuing imperialist ambitions. The Ecumenical Patriarchate stressed that it remains 
apolitical because it did not have to pursue the state's political interests, as the Russian Orthodox Church did and continues to do.

Constantinople also reminded Russia that it had granted autocephaly to the Russian Orthodox Church and other Orthodox churches. In fact, by questioning the granting of autocephaly to the Ukrainian Church, the Russian Orthodox Church is actually questioning its own independence, having received it from the same institution as the Ukrainian Church. The Russian Orthodox Church subsequently countered by claiming that the schism created by the recognition of Ukrainian autocephaly threatens the whole of Orthodoxy and weakens its influence on secular politics. By this, of course, it refers to its own weakening, for it was accustomed to influencing power relations with the support of the Russian state. This happened even when the Russian Church was under the complete control of the communist regime.

Kirill's decision not to attend the 2016 Pan-Orthodox Council in Crete was the prelude to the split. This council's planning began in the 1960s, and the presence of the Moscow Church was essential to Constantinople. The Russian Church insisted that every document of the Council must be unanimously approved by all the churches represented. The Council's venue was moved from Istanbul to Crete to accommodate the Russian government after Turkey shot down a Russian fighter jet in 2015. By that time, preparations for the Council were at their peak. However, the leaders of the Antiochian, Bulgarian, and Georgian churches announced that they would not attend unless certain documents they considered a threat to church doctrine (or its modernisation) were removed from the agenda. Whether they consulted Moscow about their refusal cannot be verified. However, what is certain is that Kirill decided not to attend the Council at the last minute. Indeed, the anti-Westernism of Russian politics has spilt over into the ecclesiastical sphere. The Moscow Patriarchate has occasionally portrayed the Ecumenical Patriarchate as a "Western" institution because of its extensive international network and ecumenical status concerning other Christian denominations. Long-standing claims by Russian politicians that the West fuelled the Maidan protests in Kyiv and other post-Soviet "colour" revolutions have reinforced this position. Putin has even openly accused the U.S. and Constantinople of collaborating to support the Ukrainian government on the path to ecclesiastical independence (Liik et al. 2019).

To counter this, Kirill visited Bartholomew in Istanbul in August 2018, where he told him: "Your Holiness, if you give Ukraine autocephaly, blood will be shed", to which the Ecumenical Patriarch replied: "Your Beatitude, we have no army or weapons at our disposal. If blood is to be shed, it will not be shed by us, but by you!" (Sherr and Kullamaa 2019, p. 16). According to Russian Orthodox leaders, Patriarch Bartholomew's decision marks the most significant schism in the Christian world in the past thousand years. According to Metropolitan Hilarion, Constantinople's move was illegal, and Moscow will not recognise it. He hopes Bartholomew will back down, but that is highly unlikely. At most, there has been an indication of the dysfunction of the Tomos in history, but that was in the case of autonomous churches. An Autocephaly Tomos has never been revoked. The Russian Church is calling on all the Orthodox churches of the world to find a way out of the "most difficult crisis" caused by the Constantinople decision. However, it is evident that a revision of the decision cannot be expected. Therefore, it would surely be wiser to seek an amicable solution instead of the empty gesture of severing relations with Constantinople. That solution includes Kyiv.

Like the Russian state, the Russian Orthodox Church has a problem with geographyKyiv is located in the territory of independent Ukraine. However, the beginning of East Slavic statehood (Kievan Rus, 982), Christianisation, and the Church's foundation (988) began there, despite the fact that it had existed for many centuries without autocephaly and subordinated to Constantinople. There was neither a Russian nor a Ukrainian nation, but statehood and the church gradually moved to another metropolis, Moscow. Although Kyiv belonged first to Lithuania, then to Poland, and subsequently to Russia, it too eventually became the centre of statehood again, this time Ukrainian. However, the situation was more complicated for the Church. The problems culminated in 2018-2019 because Russia still 
has not accepted that Kyiv was no longer part of Russian territory. It is not surprising that in 2018, Russian Patriarch Kirill declared: "It is impossible to separate Kyiv from our country because this is where our history began. The Russian Orthodox Church preserves the common national consciousness of Russians and Ukrainians". He was followed by Vladimir Putin, claiming that the primary goal of granting autocephaly to the Ukrainian Church was "to divide the people of Russia and Ukraine, to sow national and religious division" (Liik et al. 2019). He repeated the same message on his presidential website in 2021 (Путин 2021).

Thus, there is no self-reflection of the heirs of Russian colonialism, whose modern representative Putin has divided Russians and Ukrainians more than ever in history, calling Ukrainians fascists, seizing a piece of Ukrainian territory, and supporting Donbas separatism, while drowning the same problem on the territory of Russia (Chechen separatism) in blood. On the other hand, former President Petro Poroshenko compared church autonomy to the country's membership in the North Atlantic Alliance and the European Union. He accused the Kremlin of using the Church as an instrument for its influence in Ukraine (Zinets 2018).

\section{Conclusions}

Like various secular institutions, Churches have their own interests, agendas, and traditions to protect. These do not always coincide with the state's; however, this was not the case under the totalitarian Soviet regime-Church leaders were appointed by the state and fulfilled its demands. Still, even in autocratic regimes, such as Putin's Russia, the Church can oppose the state's interests-a typical example was Russia's recognition of the independence of Abkhazia and South Ossetia-Alania. At the same time, the Russian Orthodox Church refused to take over the local Orthodox believers. Moreover, after Russia had annexed Crimea, the Patriarch refused to bring the three local eparchies directly under his jurisdiction. Therefore, they remain part of the autonomous Ukrainian Orthodox Church. Kirill did not even participate in the ceremonial act of Crimea's "accession" to the Russian Federation, attended by political, military, and economic elites. It should be noted that he regularly attended far less significant acts. These events show that the Russian Orthodox Church is trying to maintain some independence in decision making. However, the question is whether the state will tolerate this independence to open a "backdoor" for the eventual return of Georgia and Ukraine to the Russian sphere of influence. In the case of Georgia, it can be assumed that Russia will simply revoke the international recognition of Abkhazia and South Ossetia-Alania. On the other hand, Russia cannot be expected to reverse the annexation decision in the case of the strategically important Crimea, which has a significant Russian population, even if the regime in Russia would possibly change.

Shortly after the annexation of Crimea, the Russian Patriarch publicly extolled the "Russian World" virtues-a concept used by the Russian media and political class to justify Russian political, military, and clerical activities in Ukraine. Kirill declared that "Russia belongs to a civilisation that is larger than the Russian Federation. We call this civilisation the Russian world. This is not the world of the Russian Federation or the Russian Empire. The Russian world begins at the baptismal font of Kyiv. Russians, Ukrainians and Belarusians belong to it" (The Russian World is a Special Civilization-Patriarch Kirill 2014). However, the Patriarch's true face has been revealed in Russia's support for the separatists in Donbas. Instead of calling for an end to the fighting and peace, he issued a statement attacking Ukrainian "uniats and razkolniks" 22 for defending their country. Subsequently, Kirill handed over the church orders to two major Russian propaganda channels during the decisive battle for the Donetsk airport in late 2014. The official justification was their service to the Church and state (Liik et al. 2019). However, these channels were instrumental in broadcasting the propaganda that led to the war in Ukraine. Kirill obviously chose a side at that time, although he initially wanted to avoid it.

The Russian Orthodox Church has made virtually the same mistake as the leaders of the Russian state led by Putin. It failed to compromise and move away from the great power perspective of Ukraine as a temporarily rebellious province that must be subjugated 
by force to follow Russian geopolitics and theopolitics. Clinging to the subordination of Ukrainian Orthodox believers to Moscow, rather than offering autocephaly and maintaining friendly relations, has brought Russia and its church an embarrassing defeat.

The Russian Orthodox Church struggles with the fact that as the Church with the highest number of believers and the support of the state, still retaining its power status, it cannot reverse the theopolitical rivalry with Constantinople. The Ecumenical Patriarchate holds strong soft power but lacks access to other levers of power compared to the Moscow Patriarchate. The Russian Orthodox Church owns billions of dollars in revenue, employs thousands of people at home and abroad, and has access to a global network of Russian diplomatic and media presence, from "Russia Today" to dozens of religious websites in many languages, to draw on. On the other hand, Constantinople possesses none of this.

Moscow was particularly angered that the Patriarch of Constantinople withdrew, as a first step, his consent to the acquisition of the Metropolitanate of Kyiv in 1686. The Russian Orthodox Church insists that Constantinople transferred its jurisdiction over Kyiv to the Moscow Patriarchate when this happened. Therefore, Kyiv has become part of the Russian diocese. Constantinople, however, claims that it only granted Moscow the right to consecrate the then-Metropolitan of Kyiv because the Ottoman government prevented the Ecumenical Patriarchate from fully exercising its jurisdiction over Kyiv. Such an interpretation of history relies on a document of the Ecumenical Patriarchate from 1686, proclaiming that the ecclesiastical control of Kyiv had been taken over uncanonically by Moscow. Bartholomew commented: “Our Patriarch, my predecessor, went to Russia to collect church revenues. However, then he was not allowed to return to Constantinople without making concessions regarding Kyiv. Thus, in 1686, Moscow received only the 'right of consecration' of the Metropolitan of Kyiv, who was obliged to mention the name of the Ecumenical Patriarch first in the liturgies. However, he did not keep this promise" (Sherr and Kullamaa 2019, p. 16). Hence, the first step before granting autocephaly was restoring Constantinople's jurisdiction over Ukraine. This happened in October 2018 and was accepted by the Ukrainian Orthodox Church-Kyiv Patriarchate and the Ukrainian Autocephalous Orthodox Church.

The ecclesiastical dispute between Russia and Ukraine can be resolved by adapting the Estonian model. However, Ukraine has faced different ecclesiastical histories, and Russia and the Russian Orthodox Church perceive it to be more significant than Estonia. From the Estonian perspective, the agreement between the two Patriarchates was crucial to resolving the stalemate; it may offer a glimmer of hope to those who want to resolve the Ukrainian problem. In Estonia, on the other hand, autocephaly was not the crux, which is crucial for Ukrainians, and relations between the Patriarchs have deteriorated significantly.

Indeed, the church dispute remains a fuse in Russian-Ukrainian relations that could explode if the Kremlin wishes. Supporters of the Russian Orthodox Church, or provocateurs within their ranks, could prevent parishes from changing their affiliation or becoming embroiled in other disputes. The risk of clashes is high, given the ongoing conflict in the Donbas border region (Brodetskyi et al. 2020).

The recognition of the autocephaly of the Ukrainian Church has caused difficulties among other churches. Gradually, it was recognised by the churches in Alexandria, Greece, and Cyprus ${ }^{23}$ - churches associated with the Greek ethnicity or influenced by the Greek tradition. ${ }^{24}$ On the other hand, the Serbian Church, which experiences similar problems to those of Russia, has vehemently opposed the recognition of autocephaly because breakaway churches in Northern Macedonia and Montenegro are also striving for autocephaly. The Georgian Church is in a difficult situation. On the one hand, it is compelled to adopt the same position as the Serbian Church because it does not want to lose the canonical territories in Abkhazia and South Ossetia-Alania. On the other hand, it is closely linked to a state and nation that has become the target of Russian aggression, just like Ukraine and Ukrainians. Geopolitically, it should join the Church of Constantinople and recognise Ukrainian autocephaly, but theoretically, it is forced to behave quite differently (Chapidze and Umland 2019). 
The question, of course, remains how many other Orthodox churches will recognise Ukrainian autocephaly. The historical overview has indicated that such a process often takes decades. Some churches face internal dissension concerning this question, with some bishops being in favour of recognition and others against it. Therefore, these churches do not rush to a decision between Moscow and Constantinople. However, their margin of manoeuvre is limited. Given that most of the other churches received autocephaly from Constantinople ${ }^{25}$ (and those granted autocephalies by the Moscow Patriarchate were recognised by the other "non-Soviet" churches only after gaining recognition by the Ecumenical Patriarchate), they cannot go too far in challenging Constantinople's right to grant the status. One Greek Metropolitan argued that "by rejecting the way the Patriarchate issued the Tomos on the autocephaly of Ukraine, the autocephalous status of the eight current autocephalous churches, including the autocephalous Church in Greece, will be called into question because they were granted by the Ecumenical Patriarchate" (Liik et al. 2019). Consequently, the recognition process is inevitable, no matter how long it takes, because autocephaly cannot be revoked.

An interesting bipolarity has developed in the Orthodox world in relation to Ukrainian autocephaly. On the one hand, there is the "Greek bloc" (Constantinople, Alexandria, Greece, Cyprus), without the Patriarchate of Antioch, and on the other hand, the "Slavic bloc" (Russia, Serbia, Poland, Czechia and Slovakia, and non-Slavic Georgia ${ }^{26}$ ), without Ukraine, whose autocephaly has given rise to the "Greek bloc". It is ironic how theopolitics differs from geopolitics in many cases. Poland's strongly anti-Russian geopolitics (influenced by traditional Catholicism) leans towards Russia in Orthodox theopolitics. Moreover, most Orthodox believers in Poland are Ukrainians, perhaps the greatest paradox (Ławreszuk 2019). Czechia and, to a lesser extent, Slovakia (Gajdoš 2019) are also prominent critics of Russian geopolitics, yet the common Orthodox Church maintains a partnership with Russia. The local Metropolitan condemned Patriarch Bartholomew's decision, calling the act "the legalisation of Ukrainian subversives" (Velký náboženský rozkol 2018).

The Church in Georgia acts similarly, although its support for Russia is reinforced by the loss of control over part of its territory and Orthodox believers in Abkhazia and South Ossetia-Alania (for details, see, e.g., Baarová 2015; Baarová 2019; Hoch and Khundadze 2017; Górecki 2020). Secular geopolitics and Orthodox theopolitics in Serbia are fundamentally in sync and have long been influenced by the collapse of socialist federations, which Russians and Serbs had dominated. Moreover, they share the same problems regarding the emancipation of "national" churches. These "Slavic" churches seek help from "Greek" Constantinople. The other churches (Jerusalem, Romanian, Bulgarian, and Albanian) adopted a neutral position in the first phase, although Ukrainian sources indicated that these churches were about to recognise Ukrainian autocephaly (Onisenko 2021).

Author Contributions: Conceptualization V.B.; methodology B.B., supervision and funding acquisition V.B. and B.B.; investigation M.S. and J.G.; resources M.S. and J.G., writing-original draft preparation V.B, writing-review and editing, M.S., B.B. and J.G. All authors have read and agreed to the published version of the manuscript.

Funding: This research received no external funding.

Institutional Review Board Statement: Not applicable.

Informed Consent Statement: Not applicable.

Data Availability Statement: Not applicable.

Conflicts of Interest: The authors declare no conflict of interest.

\section{Notes}

In the true sense of the word, the Church did not cease to exist. However, the Patriarchate was abolished and replaced by an archbishopric based in Ohrid (its official name was the Archbishopric of Justiniana Prima, Ohrid, and all Bulgaria). In 1020, the Archbishopric of Ohrid was granted autocephaly, but this was limited in that the Byzantine emperor chose the archbishop from three proposed candidates (Prinzing 2012). 
2 The difference between Tarnovo and Ohrid was that Ohrid became politically subordinate to Byzantium, but Tarnovo was not. However, the Bulgarians had to wait 50 years to be recognised by the Patriarch of Constantinople. The Bulgarians never succeeded in annexing the Archbishopric of Ohrid; thus, there were two autocephalous churches. While the Ottomans abolished the Patriarchate of Tarnovo, the Ohrid autocephaly persisted until 1767. Since Ohrid lies in Northern Macedonia, the non-canonical Macedonian Orthodox Church claims its heritage.

3 Autonomy was granted in the 1927 constitution.

4 The first four places were occupied by the traditional patriarchates of Constantinople, Alexandria, Antioch, and Jerusalem; by ranking fifth, the Russian Patriarchate leapfrogged the then-existing churches in Georgia, Bulgaria (Ohrid), Serbia, and Cyprus (the last three existed within the Ottoman Empire as the four traditional patriarchates).

5 Graphological studies conducted in the late 20th century showed that at least 70 of the 105 signatures of the participants in the Council were not genuine. Presumably, these persons left before the Council was concluded.

6 However, only for a short time-creating the autocephalous Ohrid gave the Bulgarians back their ecclesiastical independence. The later annexation of the canonical territories of the Bulgarians and Serbs stemmed from the decision of the Ottoman Sultan, although it allegedly occurred at the request of the Ecumenical Patriarch.

7 In 1814, it also abolished the Abkhazian Orthodox Church, which functioned as a de facto autocephalous institution. Its name and restoration have been the subject of the current disputes between Abkhazians and Georgians. While Abkhazians point to its name and link it to their national identity, Georgians attest that it was a Georgian church in liturgy and canonically included the West Georgian states of Abkhazia, Megrelia, Svaneti, Imereti, and Guria. Indeed, it was called Abkhazian and Imeretian from 1455, and Imeretian and Abkhazian from 1657 (Скурат 1994). Moreover, they question its autocephaly and promote the thesis of its subordination to the Georgian Church, although there is no written evidence confirming either autocephaly or subordination (Гугушвили and Виноградов 2015, 2018).

8 During the communist regime, the Russian Orthodox Church agreed to restore the autocephaly of the Georgian Orthodox Church in 1943. It was, however, carried out under pressure from Joseph Stalin, who wanted to ensure the loyalty of the Georgians in the war. On the other hand, the Patriarchate of Constantinople did not recognise the autocephaly until 1990.

9 In 1708, the Metropolitanate formed an autonomous part of the Serbian Orthodox Church; after its dissolution in 1766, it functioned autonomously under Constantinople for the Orthodox in the Habsburg Monarchy. In 1848, the Metropolitan of Karlovac received the honorary title of Serbian Patriarch. Simultaneously, the Metropolitanate of Belgrade existed in the Principality of Serbia from 1831 within the Ecumenical Church. In 1897, its autocephaly was recognised by the Ecumenical Church under the renewed name of the Serbian Orthodox Church. The latter absorbed the Metropolitanate of Karlovac and the de facto autocephalous Montenegrin Orthodox Church in 1920.

In 1926, they even allowed the registration of the Chuvash Autocephalous Orthodox Church (Берман undated; Альпаут 2018).

In 1924, the Russian Orthodox Church Outside of Russia (ROCOR) was established in exile, independent of the Communists. After 80 years of separation, following the fall of the USSR, the Russian Orthodox Church Outside Russia officially signed the Act of Canonical Communion with the Moscow Patriarchate on 17 May 2007. By doing so, canonical communion between the churches was restored. A schism was thus created, resulting in the creation of the Russian Orthodox Church Abroad-a provisional supreme ecclesiastical authority that remained independent of the Moscow Patriarchate.

Moscow, of course, did not recognise the autocephaly; the name was changed to the Orthodox Church of the General Gouvernement during the German occupation (1941-1944).

13 After establishing the communist regime in Poland and installing KGB agents at the head of the Polish Church, a unique situation occurred-the Polish Church renounced the 1924 autocephaly and asked Moscow to grant it (Krzystofiński and Sychowicz 2008). Constantinople did not recognise the act of abrogating the 1924 Tomos, which means that it continued to consider the PPC autocephalous (Bystrytska and Volik 2021).

In the same year, the Georgian Patriarchate was restored. By doing so, Stalin, facing a difficult military situation, tried to win the Orthodox believers to his side.

15 Alexei I received some support only in Antioch, which persists to this day. The support of the Russian Orthodox Church is furthermore influenced by Russia's political support for the Syrian regime, with whom the Antiochian Church cooperates.

After the split of Czechoslovakia into the Czech Republic and Slovakia, the Church remained united but changed its name to the Orthodox Church of the Czech Lands and Slovakia. However, it was recognised by Constantinople and the other old patriarchates only in 1997.

At that time, Moscow reacted to the request of several bishops of Russian origin who did not appreciate the emergence of several ethnically based Orthodox churches in the USA under the jurisdiction of traditional patriarchates. Interestingly, the then Russian Orthodox Greek Catholic Church in America broke off relations with the Russian Orthodox Church in 1924 and became independent. Later, in 1935, it established relations with the Russian Orthodox Church Abroad but broke with it after the war. At the 1946 Synod, it was decided to resume relations with the Russian Orthodox Church, which, however, refused to grant it autonomy. Thus, it remained independent. The new negotiations began in 1968 and ended with granting a tomos on autocephaly and a change in name to the Orthodox Church of America. Interestingly, even the military occupation of Czechoslovakia did 
not deter the American bishops from dealing with the Church, which was entirely under the control of the Communist state and the KGB. Only the churches of the USSR-controlled countries recognised autocephaly (Georgian, Bulgarian, Czechoslovak, and Polish; the others firmly rejected it; only the Serbian Church pertained a neutral position). Nothing changed even after the collapse of the USSR.

From 1774, during the Austrian occupation of Polish territory (Halych), the Church was called the Greek Catholic Church; the Papal yearbook of 1912 referred to it as the Ukrainian Catholic Church of the Byzantine Rite. In the Ukrainian diaspora in 1960, it was called the Ukrainian Catholic Church, and according to the Synod of 1999, it is officially called the Kyivan Catholic Church in Ukraine.

In 1722, the title was "Archbishop of Kyiv and Halych"; it changed to "Metropolitan of Kyiv and Halych" in 1730, but without the suffix "of all Little Russia". Halych = Galicia.

20 The same decision was taken in 1936 on the autonomy of the Latvian Church.

21 The Orthodox Estonians call themselves Setos, and their language is a dialect of Estonian.

22 Razkolnik is Russian word for heretic.

23 The vote among the bishops in Cyprus was quite close, ten to seven (Dubas 2020).

24 The Greek Orthodox Church of Alexandria still uses Greek as its liturgical language. Dissatisfaction with Greek (Byzantine) influence led, as early as the 3rd-4th century, to the separation of the Miaphysite Coptic Orthodox Church of Alexandria, which replaced Greek with Coptic (the indigenous Egyptian language) in the liturgy. However, Coptic was gradually replaced by the Arabic language but is still used today for liturgical purposes. The Coptic script partly evolved from the Greek alphabet. The Coptic faithful outnumber the Greek Orthodox by about ten to one.

Only the Cypriot Church adopted it from the Antiochian Church, as did the original Georgian Church. After being absorbed by the Russian Church, it regained autocephaly therefrom. Other churches existing outside the Soviet bloc recognised it only after Constantinople did so. The American Church has already been discussed.

26 Additionally, of course, also the American Church because Moscow granted it autocephaly. However, this Church has not publicly commented on the Ukrainian autocephaly.

\section{References}

Anderson, Braden P. 2010. Chosen Nation: Biblical Theopolitics and the Problem of American Christian Nationalism/dissertation/. Milwaukee: Marquette University, Available online: https:/ / epublications.marquette.edu/cgi/viewcontent.cgi?article=1063\&context= dissertations_mu (accessed on 13 July 2021).

Альпаут, Рамазан. 2018. Чувашская автокечальная церковь просуществовала около десяти лет. Idel Realii. October 18. Available online: https: / / www.idelreal.org/a/29546780.html (accessed on 15 July 2021).

Baarová, Barbara. 2015. Religious Policy in de Facto States of Caucasus-Abkhazia and South Ossetia. In SGEM 2015: International Multidisciplinary Scientific Conference on Social Sciences and Arts: Political Sciences, Law, Finance, Economics and Tourism, vol. 1. Sofia: SGEM, pp. 291-98.

Baarová, Barbara. 2019. South Ossetia-Alania-10 Years since Gaining Partial International Recognition. Politické vedy 22: 159-88. [CrossRef]

Вагнер, Олександра. 2018. Дві правди. Частина українських православних залишиться з Москвою. Radio Svoboda. November 15. Available online: https:/ / www.radiosvoboda.org/a/29601905.html (accessed on 15 July 2021).

Biserica Adevarat Ortodoxă din Moldova și Alții. 2007. Available online: http://agent.gov.md/biserica-adevarat-ortodoxa-dinmoldova-si-altii/ (accessed on 15 July 2021).

Bogdanas, Ramūnas. 2019. A Question for Orthodox Believers in Lithuania. Lithuania Tribune. January 19. Available online: https:/ / lithuaniatribune.com/ramunas-bogdanas-a-question-for-orthodox-believers-in-lithuania/ (accessed on 14 July 2021).

Bogdanović, Jelena. 2016. The Relational Spiritual Geopolitics of Constantinople, the Capital of the Byzantine Empire. In Political Landscapes of Capital Cities. Edited by Jessica J. Christie, Jelena Bogdanović and Eulogio Guzmán. Boulder: University Press of Colorado, pp. 97-154.

Boronas, Darius. 2013. LDK istorija: Lietuvos Stačiatikiu Metropolija (1316-1458). 15min aktualu. December 20. Available online: https: //www.15min.lt/naujiena/aktualu/istorija/ldk-istorija-lietuvos-staciatikiu-metropolija-1316-1458-582-393746?copied (accessed on 18 July 2021).

Brodetskyi, Oleksandr, Iryna Horokholinska, and Mykola Lahodych. 2020. Ukraine Orthodoxy Autocephaly: Social and Value Challenges. Occasional Papers on Religion in Eastern Europe 40: 22-44. Available online: https:/ / digitalcommons.georgefox.edu/ cgi/ viewcontent.cgi? article=2224\&context=ree (accessed on 12 August 2021).

Brody, Samuel H. 2015. Is Theopolitics an Antipolitics? Martin Buber, Anarchism, and the Idea of the Political. In Dialogue as a Trans-Disciplinary Concept: Martin Buber's Philosophy of Dialogue and Its Contemporary Reception. Edited and Paul by Mendes-Flohr. Berlin: De Gruyter, pp. 61-88.

Brody, Samuel H. 2018. Martin Buber's Theopolitics. Bloomington: Indiana University Press.

Buber, Martin. 1932. Königtum Gottes (Kingship of God). Berlin: Schocken Verlag. 
Bystrytska, Ella, and Nadia Volik. 2021. The Question of the Autocephalous Status of the Polish Orthodox Church in the Documents of the Council for the Affairs of the Russian Orthodox Church (1944-1948). Occasional Papers on Religion in Eastern Europe 41: 20-36. Available online: https: / / digitalcommons.georgefox.edu/cgi/viewcontent.cgi?article=2256\&context=ree (accessed on 17 July 2021).

Воронин, Олександер. 1992. Історія УАПЦ. Частина 4. Утиски УАПЦ В 20-х і 30-х роках. Patriarcha.org. Available online: https:/ / patriarchia.org.ua/istoriya-uapc-chastina-4-utiski-uapc-v-20-x-i/?lang=ru (accessed on 1 August 2021).

Chapidze, Tamar, and Andreas Umland. 2019. Complications in Tbilisi's Friendship with Kyiv. Harvard International Review 40: 30-32. Available online: https:/ / www.atlanticcouncil.org/blogs/ukrainealert/complications-in-tbilisi-s-friendship-with-kyiv / (accessed on 10 July 2021).

Скурат, Константин Е. 1994. История Поместных Православных Церквей. Азбука веры-Православная библиотека. Аvailable online: https:/ / azbyka.ru/otechnik/Konstantin_Skurat/istorija-pomestnyh-pravoslavnyh-tserkvej/ (accessed on 2 July 2021).

Dubas, Matthew. 2020. Synod of Cyprus Votes to Recognize OCU. The Ukrainian Weekly. December 4. Available online: https: //www.ukrweekly.com/uwwp/synod-of-cyprus-votes-to-recognize-ocu/ (accessed on 4 July 2021).

Gajdoš, Marcel. 2019. Čo sa stalo na Ukrajine? Svet křest'anstva. January 10. Available online: https://svetkrestanstva.postoj.sk/39467/ co-sa-stalo-na-ukrajine?fbclid=IwAR2BR6Q8KXyz7TpP8bfTyT96MbFfXKyJmoVzU0Efdfjx6hMkgQw42NML7tM (accessed on 15 July 2021).

Górecki, Wojciech. 2020. The Autumn of the (Georgian) Patriarch. The Role of the Orthodox Church in Georgia and in Georgian Politics. OSW Commentary No. 332. Available online: http:/ / aei.pitt.edu/103304/1/OSW_Commentary_332(1).pdf (accessed on 15 July 2021).

Hoch, Tomáš, and Tato Khundadze. 2017. Pravoslavné církve a transformace gruzínsko-abcházského konfliktu. Mezinárodní vztahy 52: $7-22$.

Karagiannis, Emmanuel. 2018. The New Political Islam. Human Rights, Democracy, and Justice. Philadelphia: University of Pennsylvania Press.

Каиль, Максит. 2017. Православный фактор в советской дипломатии: международные коммуникации Московского Патриархата середины 1940-х гг. Государство, религия, церковь в России и за рубежом. No. 1. pp. 19-39. Available online: https:/ / cyberleninka.ru/article/n/pravoslavnyy-faktor-v-sovetskoy-diplomatii-mezhdunarodnye-kommunikatsiimoskovskogo-patriarhata-serediny-1940-h-gg/viewer (accessed on 6 August 2021).

Kormina, Jeanne, and Vlad Naumescu. 2020. A new 'Great Schism'? Theopolitics of Communion and Canonical territory in the Orthodox Church. Antropology Today 36: 7-11. Available online: https://rai.onlinelibrary.wiley.com/doi/pdf/10.1111/1467-8322. 12551 (accessed on 5 August 2021). [CrossRef]

Krzystofiński, Mariusz, and Krzysztof Sychowicz. 2008. W kręgu „Bizancjum”, „Aparat Represji w Polsce Ludowej 1944-1989”. nr 1: 79-154.

Кишиневский, Денис. 2019. Замахнулись на святое. Латвия и Литва хотят отделить свою церковь от РПЦ. Их вдохновил раскол на Украине. Lenta. July 11. Available online: https://lenta.ru/articles/2019/07/11/baltic/ (accessed on 5 August 2021).

Ławreszuk, Marek. 2019. PAKP i uznanie ukraińskiej autokefalii. Ekumenizm. Available online: https://www.ekumenizm.pl/ koscioly/wschodnie/pakp-i-uznanie-ukrainskiej-autokefalii/ (accessed on 2 August 2021).

Leonidov, Sergey, and Igor Prekop. 2019. Baltic Rehearsal. How the Patriarchate of Constantinople Solved the Issue of Estonian Orthodoxy. In Russia in Global Affairs. No. 2.1, Special Issue. Available online: https://eng.globalaffairs.ru/articles/balticrehearsal/ (accessed on 1 August 2021).

Liekis, Šarūnas. 2019. Ukrainiečiu Autokefalijos Aidas Lietuvoje. Alfa. April 16. Available online: https://www.alfa.lt/straipsnis/5038 5427 / ukrainieciu-autokefalijos-aidas-lietuvoje/ (accessed on 1 August 2021).

Liik, Kadri, Momchil Metodiev, and Nicu Popescu. 2019. Defender of the Faith? How Ukraine's Orthodox Split Threatens Russia. European Council on Foreign Relations. May 30. Available online: https://ecfr.eu/publication/defender_of_the_faith_how_ ukraines_orthodox_split_threatens_russia/ (accessed on 22 July 2021).

March, Andrew F. 2015. Political Islam: Theory. Annual Review of Political Science 18: 103-23. [CrossRef]

Moore, Thomas. 2020. On the theopolitics of sovereignty: Carl Schmitt and the theopolitics of global orders. Review of International Studies 46: 691-712. [CrossRef]

Onisenko, Kostas. 2021. Metropolitan of Kyiv: Georgia, Jerusalem, Romania, Ready to Recognize the Church of Ukraine. Orthodox Times. January 12. Available online: https: / / orthodoxtimes.com/metropolitan-of-kyiv-georgia-jerusalem-romania-ready-torecognize-the-church-of-ukraine/ (accessed on 20 July 2021).

Одинцов, Михаил И. 1994. Русские патриархи ХХ века. Москва: Издательство РАГС.

Ponomariov, Alexander. 2019. Theopolitics on the Grand Chessboard: Ukraine between the Church Canons and the Canons of War. Zurich University Working Paper No. 2. pp. 3-16. Available online: https://www.cees.uzh.ch/dam/jcr:305943d1-de5a-4be2-929b-9a5 61805e27b /CEES\%20Working\%20Paper\%20No_2\%202019.pdf (accessed on 23 July 2021).

Prinzing, Günter. 2012. The autocephalous Byzantine ecclesiastical province of Bulgaria/Ohrid. How independent were its archbishops? Bulgaria Mediaevalis 3: 355-83.

Rimestad, Sebastian. 2012. From Empire to Nation State: The Consolidation of the Relationship between the Orthodox Church and Independent Lithuania and Latvia after the First World War. Białystok: Studia Podlaskie tom XX, pp. 211-23. Available online: https:// repozytorium.uwb.edu.pl/jspui/bitstream/11320/392/1/Studia_Podlaskie_20_Rimestad.pdf (accessed on 1 August 2021). 
Sayyid, Salman. 2009. Answering the Muslim question: The Politics of Muslims in Europe. Open Edition, e-Cadernos CES. Available online: https:/ /journals.openedition.org/eces/180 (accessed on 20 July 2021).

Schaefer, Yoav. 2017. Between Political Theology and Theopolitics: Martin Buber's Kingship of God. Modern Judaism 37: 231-55. [CrossRef]

Scott, Rachel M. 2010. The Challenge of Political Islam. Non-Muslims and the Egyptian State. Stanford: Standford University Press.

Sherr, James, and Kaarel Kullamaa. 2019. The Russian Orthodox Church: Faith, Power and Conquest. Tallinn: International Centre for Defence and Security. Available online: https://icds.ee/wp-content/uploads/2019/12/ICDS_EFPI_Report_The_Russian_ Orthodox_Church_Sherr_Kullamaa_December_2019.pdf (accessed on 1 August 2021).

Slavov, Atanas. 2016. Towards Participatory Political Theology: Democratic Consolidation in Southeastern Europe and the Role of Eastern Christianity in the Proces. Ph.D. thesis, University of Glasgow, Glasgow. Available online: http://theses.gla.ac.uk/7337 /1/2016SlavovPhD.pdf (accessed on 15 July 2021).

The Russian World is a Special Civilization-Patriarch Kirill. 2014. Russkiy mir Foundation. September 9. Available online: https: // russkiymir.ru/en/news/149812/ (accessed on 4 August 2021).

Tomos of Autocephaly. 1970. Orthodox Church of America. Available online: https://www.oca.org/history-archives/tomos-ofautocephaly (accessed on 4 August 2021).

Velký náboženský rozkol. 2018. Ruská církev ruší kvůli Ukrajině veškeré styky s konstantinopolským patriarchátem. Lidovky. October 15. Available online: https://www.lidovky.cz/svet/velky-nabozensky-rozkol-ruska-cirkev-zastavuje-kvuli-ukrajine-veskerestyky-s-konstantinopolskym-pat.A181015_185304_ln_zahranici_pev (accessed on 5 August 2021).

Werth, Paul. 2006. Georgian Autocephaly and the Ethnic Fragmentation of Orthodoxy. Acta Slavica Iaponica 23: 74-100. Available online: https://src-h.slav.hokudai.ac.jp/publictn/acta/23/03_werth.pdf (accessed on 15 July 2021).

Zinets, Natalia. 2018. Ukraine Moves to Split Church from Russia as Elections Approach. Reuters. April 19. Available online: https:/ / www.reuters.com/article/us-ukraine-church-idUSKBN1HQ1ZA (accessed on 15 July 2021).

Фаустова, Милена. 2021. Автокефалия-теперь главное пугало “русского мира». Независимая газета религии. August 3. Available online: https://www.ng.ru/ng_religii/2021-08-03/9_512_autocephaly.html (accessed on 14 July 2021).

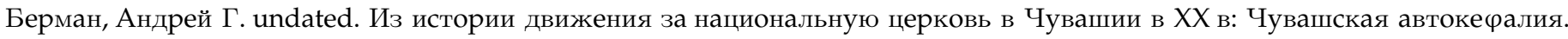
Available online: https:/ / xn--80ad7bbk5c.xn--p1ai/ru/content/iz-istorii-dvizheniya-za-nacionalnuyu-cerkov-v-chuvashii-vxx-v-chuvashskaya-avtokefaliya (accessed on 20 July 2021).

Грамота об утверждении Московского патриархата. 100 главных документов российской истории. undated. Available online: https:/ / doc.histrf.ru/10-16/gramota-ob-utverzhdenii-moskovskogo-patriarkhata/ (accessed on 14 August 2021).

Гугушвили, Шота, and Андрей Ю Виноградов. 2015. Очерк истории абхазского католикосата. Часть 1. VIII-X вв. Богословские труды, выпуск. Москва: Издательство Московской Патриархии Русской Православной Церкви, vol. 46, pp. 77-116.

Гугушвили, Шота, and Андрей Ю Виноградов. 2018. Очерк истории абхазского католикосата. Часть 2. XI-XV вв. Богословские труды, выпуск. Москва: Издательство Московской Патриархии Русской Православной Церкви, vol. 47-48, pp. 290-320.

Петров, Иван В. 2013. Проблема Литовско-белорусской православной автокечалии в начале Второй мировой войны (19391940). Bylye Gody 29: 96-100.

Приймак, Артур. 2019. Константинополь пытается вытеснить РПЦ из Латвии. Независимая газета религии. Осtоber 10. Available online: https:/ /www.ng.ru/facts/2019-10-01/9_473_latvia.html (accessed on 21 July 2021).

Путин, Владимир В. 2021. Статья Владимира Путина «Об историческом единстве русских и украинцев». Kremlin. July 12. Available online: http:/ / kremlin.ru/events/president/news/66181 (accessed on 21 July 2021). 